\title{
Sugar Cane Refining And Processing Company: A Comprehensive Case In Measuring A Firm's Cost Of Capital
}

Denis O. Boudreaux, University of Louisiana at Lafayette, USA

S. P. Rao, University of Louisiana at Lafayette, USA

Praveen Das, University of Louisiana at Lafayette, USA

\begin{abstract}
The Sugar Cane Refining and Processing Company is a comprehensive case illustrating how a firm's financial manager should calculate the firm's cost of capital. Senior level undergraduate and graduate corporate financial management courses cover advanced topics in cost of capital and applying the rate in capital budgeting. To cover this relevant topic in a single case, the invented or "armchair" approach is used. This case is completely contrived but is very educationally effective.
\end{abstract}

Keywords: Cost of Capital; Required Rate of Return; Hurdle Rate for Capital Budgeting

\section{INTRODUCTION}

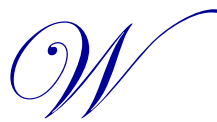

hat is a firm's cost of capital? A firm's cost of capital is precisely as its name implies. When a firm raises capital from its lenders and owners, both investors require a return on their investment. Debt investors (lenders) expect to be paid interest on their loans and equity investors require dividends or capital appreciation as their return.

The measure of a firm's cost of capital is critically important for the following reasons:

1. In order to understand causality or Positive Theory the calculation of the cost of capital has to be found under different capital structures or capital mixes so as to determine if capital structure influences the cost of capital. If a firm uses a $40 \%$ debt and $60 \%$ equity mix and has an overall cost of capital of $10 \%$ and an identical type firm uses a financing mix of $45 \%$ debt and $55 \%$ equity and has a total cost of capital of $10.5 \%$ then we may conclude that an increase of debt from $40 \%$ to $45 \%$ for this type of firm increases the firm's overall cost of capital.

2. Maximizing the value of a firm requires that the cost of all inputs or expenses be minimized; this includes the financing of the firm. To advance or recommend a certain financial mix such as the use of a certain percentage of debt in the financing structure requires knowledge of the cost of capital (Normative Theory). To minimize the cost of financing, we must be able to measure it and empirically study this phenomenon.

3. Investment decisions involving fixed assets or what is most often referred to as capital budgeting are extremely important to the firm's success, cash flows, risk and to a very large part, its market value (Bierman \& Smidt, 1988). Many financial economists consider capital budgeting to be the most important decision involving the financial manager. Finance research has made major advances in theory that provide the tools to correctly evaluate capital investment decisions. These tools are taught in undergraduate and graduate finance classes (for an excellent reference book see Brigham \& Gapenski, 2008). The estimate of the true increment cash flows and discounting those projected cash flows to present value at the appropriate required rate of return has proven to be the correct theoretical method to value a capital project (Woods \& Randall, 1989). This process requires the financial manager to use a discount rate in the valuation process. The discount rate used in capital budgeting for a company's normal or average risk project should be the company's Weighted Average Cost of Capital 
(Beranek, 1977). If the project is more or less risky than the average company's project risk, the WACC should be adjusted to capture the difference in risk. To do a proper capital budgeting analysis, the cost of capital is a prerequisite.

\section{THE CASE}

Patricia Hotard, the Chief Executive Officer of Sugar Cane Refining and Processing Company (SCRPC), picked up the telephone to call Jimmy Breez, the firm's financial manager. Breez had sent her an email earlier that morning suggesting that the capital budgeting committee should get together prior to the scheduled Investment Decision Committee meeting that is in one week to discuss how the SCRPC's cost of capital should be computed.

SCRPC began its operations over 50 years ago as a cane sugar refinery. Its first plant is located on the outskirts of a mid size city in south Louisiana in the heart of sugar cane farming. It was the first sugar refinery to locate in the heart of what was a newly developing sugar cane growing area, and it remains by far the largest processor in the region. For the first 30 years, SCRPC sold its processed sugar to soft drink bottlers and candy manufacturers at a very small profit margin. In the last twenty years, SCRPC decided to use some of the sugar to manufacturer its own finished good products. The firm added two production facilities that manufacture hard candy, mints, and cotton candy. Recently the firm added another refinery in western Louisiana to service the many cane farmers located in that region. Although a conglomerate acquired the company in the 1960's, it continues to operate autonomously. In addition to the title of Chief Executive Officer of SCRPC, Patricia Hotard also serves as a vice-president of the parent conglomerate in charge of agricultural product operations.

Hotard called Breez and listened to his reasons for the request. Breez told her last year, many of the executives and members of the board of the firm who are members of the Investment Decision Committee did not fully understand the concept of cost and capital and its application to capital budgeting. Breez believed that the committee did not use a required rate of return to analyze the projects but looked at the project's payback period and its internal rate of return (IRR). He remembers the committee voting to implement a project with a short payback and an IRR of 9 percent one year and the very next year rejecting two projects with an IRR of over 11 percent but long payback periods. Breez believes the committee may have voted against some projects that could have added value to the company while voting for some projects that would not predict an adjusted positive Net Present Values. Breez cautioned that SCRPC's market value had declined during the past year while its three main competitors actually increased in market value. Breez thought much of this poor performance was due to improperly measuring the firm's cost of capital and making errors in selecting the best capital budgeting projects.

"Your suggestion interests me," said Patricia, "I believe you should prepare a three to four hour seminar to educate our committee. I had a finance class in my MBA program and we covered capital budgeting and cost of capital but that was many years ago. I could use a refresher course. We will meet Thursday of next week and you can educate us about capital budgeting and cost of capital. Also, after the class, hopefully we will decide how we should establish a required return and which capital budgeting projects we will forward to corporate headquarters as our investments for next fiscal year."

Breez went to work preparing for his seminar next week and Investment Decision Committee meeting. He reviewed several finance textbooks that cover cost of capital and gathered the financial information needed (see exhibits).

Breez found that the determination of a firm's cost of capital should be a systematic process and include the following steps:

\section{Steps}

1. To determine the cost of capital, first identify each component that makes up the firm's long-term financing mixture.

2. Determine each individual component's before tax and after tax cost. 
3. Determine the weights or contribution of each component to the firm's capital structure and prepare a Cost of Capital Matrix.

4. Find the Break Point for Retained Earnings.

\section{APPLICATION OF STEPS}

\section{Step 1}

The first step is to identify the components that make up the long-term capital structure. In capital budgeting, any expected spontaneous changes in working capital appear in the estimate of the incremental cash flows. So to avoid a double-counting of these current asset and current liability accounts, they should not be included in the measure of a firm's cost of capital. Short-term debts, such as notes payable (which are not generated spontaneously) are not included in the capital budgeting incremental cash flow. If notes are used to finance long-term assets and they are actually continuously renewed, then this debt should be included in the firm's cost of capital estimate. If this short-term debt is used only as temporary financing to support cyclical or seasonal needs then it should not be included. Using short-term notes for permanent financing is quite risky and most firms attempt to avoid unnecessary risk. For most firms the relevant capital components for cost of capital are:

1. portion of short-term notes that is considered permanent financing;

2. all long-term debt;

3. all preferred stock; and

4. all common equity.

\section{STEP 2}

Each component's before tax and after tax cost is calculated.

\section{Debt}

If a firm is using short term notes to finance long-term investments, the interest rate that the firm would be charged for a new bank loan is the before tax rate component. The before rate would be multiplied by 1 minus the firm's marginal tax to find the after tax rate. Most firms use commercial bonds for long-term debt financing. The calculation for the use of bonds for financing is found by finding the current required yield and adjusting this yield to reflect the true after tax cost of debt to the firm if it were to issue bonds today (adjust for floatation costs and taxes). Flotation costs normally run about 1 to $2 \%$ of the issue (private placement are even less). The tax adjustment is to multiply the before tax yield by 1 minus the tax rate.

\section{Preferred Stock}

Investors purchase preferred stock for its dividend. The dividend can be viewed as a perpetual cash flow. Why, the firm does not have to pay the dividend? The firm will make every effort to pay the dividend. If they fail to do so (1) they cannot pay common stock dividends; (2) the market will not like this action (it is a very negative signal to the market about the future prospects of the firm) and the firm will have great difficulty raising additional funds in the markets (money, capital, and financial intermediaries); and (3) sometimes the preferred shareholders can assume control of the firm. There is not a tax adjustment for preferred stock. The cost of this component is the required yield to investors adjusted for floatation costs. Flotation cost generally is around 2 to $3 \%$ of par value.

\section{Common Stock}

Investors purchase preferred stock for its dividend and its capital appreciation. A firm can raise common stock equity in two ways. First, the firm can use its retained earning which are profits that were not distributed to the shareholders and are retained by the firm which increases the common stock's retained earnings account. A firm can also issue new common stock. Therefore, there are two different types of common equity and two different costs. 


\section{Retained Earnings}

The cost of debt and the cost of preferred stock are based on the return required of the investors. This will also be the case for common stock. For the existing common stock holders, the retained earnings' cost is the rate the shareholders could earn on alternative investments of similar risk. After all, the firm can either distribute the earning to the shareholders or retain the money and reinvest it in the firm.

\section{New Common Stock}

If the firm exhausts all of its retained earnings for a period and wants to maintain its optimal capital structure, then it will have to issue new common stock. The cost of new common stock is usually much higher than retained earnings because there will be flotation costs to issue new stock and most likely the stock price will fall because of the announcement to issue additional common stock.

\section{STEP 3}

Determine the weights or contribution of each component to the firm's capital structure (use the firm's target capital structure). Prepare a Cost of Capital Matrix by multiplying each component's cost with the component's weight to get the component contribution to the firm's weighted cost of capital. Sum up all contributions to find the weighted average cost of capital (WACC).

\section{STEP 4}

Find the "Break Point" for Retained Earnings. The "Break Point" is when retained earnings will be expired or depleted and the firm will have to sell new common stock to maintain the firm's optimal capital structure.

Exhibit I: Excerpts from Breez's Notes from His Cost of Capital Research

1. The cost of capital is really the required rate of return or hurdle rate that a firm should use to evaluate capital budgeting projects of average risk.

2. The cost of capital is a weighted average of the required return for each financing source. The weights should be based on market values and should be representative of the firm's optimal capital mix.

3. All debt should not be included. Spontaneous sources like accruals and accounts payable should not be counted. Notes payable should only be included if the firm is using bank loans as a permanent source of long-term financing.

Exhibit II: Historical Estimates of Yearly Returns on Certain Investments: 1926 - 2004

\begin{tabular}{|l|c|c|c|}
\hline \multicolumn{1}{|c|}{ Investment } & Arithmetic Return & Geometric Return & Standard Deviation \\
\hline Common Stocks & $12.39 \%$ & $10.43 \%$ & 20.32 \\
\hline Long-term Government Bonds & $5.82 \%$ & $5.44 \%$ & 9.30 \\
\hline T-Bills & $3.76 \%$ & $3.72 \%$ & 3.14 \\
\hline Inflation & $3.12 \%$ & $3.04 \%$ & 4.32 \\
\hline Historic Equity Premium (Gov. Bonds) & $6.57 \%$ & $4.99 \%$ & \\
\hline Historic Equity Premium (Gov. Bills) & $8.63 \%$ & $6.71 \%$ & \\
\hline
\end{tabular}

Source: Ibbotson Associates, Stocks, Bonds, Bills, and Inflation, Valuation Edition, 2006 Yearbook.

Exhibit III: SCRPC's EPS and DPS Information

\begin{tabular}{|l|c|c|c|c|}
\hline \multicolumn{1}{|c|}{ Year } & EPS & Change (\%) & DPS & $(\%)$ \\
\hline 2007 & $\$ 1.72$ & & $\$ 0.92$ & \\
\hline 2008 & $\$ 1.84$ & 3.98 & $\$ 0.96$ & 4.34 \\
\hline 2009 & $\$ 2.85$ & 54.89 & $\$ 1.01$ & 5.50 \\
\hline 2010 & $\$ 3.25$ & 14.04 & $\$ 1.06$ & 4.95 \\
\hline 2011 & $\$ 3.12$ & -4.00 & $\$ 1.10$ & 3.77 \\
\hline 2012 & $\$ 3.15$ & 0.96 & $\$ 1.16$ & 5.45 \\
\hline 2013 Projected & $\$ 3.35$ & 6.35 & $\$ 1.22$ & 5.17 \\
\hline
\end{tabular}




\section{Exhibit IV: SCRPC's Balance Sheet Information (\$000s)}

\begin{tabular}{lr}
\multicolumn{2}{c}{ Exhibit IV: SCRPC's Balance Sheet Information (\$000s) } \\
\hline & BOOK \\
Accounts Payable & $\$ 120,124$ \\
Accruals and Other Current Liabilities & 64,111 \\
Notes Payable (for working capital) & 58,125 \\
TOTAL CURRENT LIABILITIES & 242,360 \\
& \\
Long-term Debt & 275,000 \\
TOTAL LIABILITIES & 517,360 \\
& \\
Preferred Stock (par \$100) & 5,000 \\
Common Equity (\$1 par) & 10,000 \\
Excess of Par & 40,000 \\
Retained Earnings & 458,445 \\
TOTAL LIABILITIES AND EQUITY & $\underline{4,030,805}$ \\
\hline
\end{tabular}

Exhibit V: Market, Industry, and SCRPC's Financial Information

\begin{tabular}{|l|l|}
\hline Treasury Bill Rate & $4.25 \%$ \\
\hline Long-term Government Bond Yield & $7.45 \%$ \\
\hline Long-term Corporate Bond Yield & $8.75 \%$ \\
\hline Average Beta for Industry & 1.25 \\
\hline SCRPC'S Beta & 1.45 \\
\hline Average P/E Ratio for Industry & 13.50 \\
\hline SCRPC'S Recent P/E Ratio & 10.75 \\
\hline Recent Price of SCRPC's Common Stock & $\$ 36.01$ \\
\hline SCRPC's Tax Rate & $40 \%$ \\
\hline SCRPC's Bond Risk Premium & $4.0 \%$ \\
\hline
\end{tabular}

SCRPC's Bond's are selling at $\$ 910$ with a Coupon. Rate of 7.25 and maturity of 14 years. Floatation costs for the bonds would be $\$ 5$ per bond. SCRPC's preferred stock ( $\$ 100$ par) pays a $\$ 14$ dividend and is selling for $\$ 110$. The firm would have a $\$ 5$ floatation cost if it sold preferred stock today. If SCRPC sold additional common stock, the floatation cost and the decline in value would be about $20 \%$ of the current price.

Exhibit VI: Find the WACC (using Retained Earnings)

\begin{tabular}{lcccc}
\hline \multicolumn{1}{c}{ Component } & After Tax Cost & Market Value (000's) & Weight & Contribution \\
\hline Notes Payable & - & - & - & - \\
Bonds & - & - & - & - \\
Preferred Stock & - & - & - & - \\
Common Stock & - & - & - & TOTAL \\
\hline
\end{tabular}

\begin{tabular}{lcccc}
\multicolumn{5}{c}{ Exhibit VII: Find the WACC (using New Common Stock) } \\
\hline \multicolumn{1}{c}{ Component } & After tax Cost & Market Value (000's) & Weight & Contribution \\
\hline Notes Payable & - & - & - & - \\
Bonds & - & - & - & - \\
Preferred Stock & - & - & - & - \\
Common Stock & - & - & TOTAL \\
\hline
\end{tabular}

\section{QUESTIONS}

1. SCRPC uses notes to finance its working capital and its seasonal needs. Should the firm use its cost of notes in the measure of the cost of capital?

2. Estimate the firm's after-tax cost for long debt. Why do analysts use the after-tax measure in the calculation of a firm's cost of capital?

3. Calculate SCRPC's cost for preferred stock. Why is there not a tax adjustment? 
4. Calculate the cost for the current common stock investors.

(a) Estimate the cost for common stock using the Gordon Model (dividend valuation model).

(b) Calculate the cost of common stock using the Capital Asset Pricing Model.

(c) Find the cost of common stock using Bond Risk Premium Approach.

5. Calculate SCRPC's cost of capital when retained earnings is the source of common stock financing and the Gordon Model estimate is used. Use current market values of the financial instruments to determine the components weights (see Exhibit VI).

6. What is SCRPC's cost of capital when the firm has to issue new common stock and the Gordon Model estimate is used? (See Exhibit VII).

7. Calculate the "Break Point" that is when the firm while maintaining its exact optimal structure would have to start issuing new common stock for additional capital. The equation to find the Break Point is:

Break Point $=$ Retained Earnings for the Period / Weight of Common Stock

8. Draw a graph representing the firms' Marginal Cost of Capital. Label the vertical line dollars and name the horizontal line as interest rate. The graph should illustrate SCRPC's cost of capital.

9. Should market values or book values be used in the estimation of a firm's cost of capital. Defend your recommendation.

10. Preferred stock is more risky than long-term debt yet in many instances the yield to the bond holder is higher than to the preferred stockholder. Explain this paradigm.

\section{LEARNING BENEFITS}

Students will have to use important critical thinking skills to complete the assignment. The measure of incremental cash flows for the project requires a good understanding of sunk costs as well as opportunity costs. Important finance theories are covered including measuring the cost of the different financing instruments, understanding the optimal capital structure, and determining the marginal weighted average cost of capital. After successfully completing this case, the student will have demonstrated a thorough knowledge of capital budgeting.

\section{AUTHOR INFORMATION}

Denis O. Boudreaux is an Associate Professor of Finance at the University of Louisiana at Lafayette. Some of his research interests include capital market efficiency, capital budgeting, valuing and measuring the cost of capital for small privately held firms. He has published in many refereed journals including Business and Economic Review, Journal of Business \& Economics Research, Southwestern Economic Review, and the Journal of Economics and Finance. Dr. Boudreaux is a practicing forensic economist. E-mail: denis.boudreaux@lusfiber.net (Corresponding author)

S. P. Rao is a full professor at the University of Louisiana at Lafayette. His research interests lie in the field of investments, especially asset pricing, portfolio theory, optimization, capital market efficiency, and evaluation of mutual funds. Dr. Rao has published peered reviewed articles in journals such as Journal of Business Ethics, Global Finance Journal, Managerial Finance, Southwestern Economic Review, Journal of Economics and Finance, International Business \& Economics Research Journal, and the Journal of Accounting and Finance Research. E-mail: smr8609@louisiana.edu

Praveen Das is an assistant professor at the University of Louisiana at Lafayette. Dr. Das' interest in research is in the area of investments, especially portfolio theory, capital market efficiency, international finance, and evaluation of mutual funds' performance. Dr. Das has published peered reviewed articles in journals such Managerial Decision Economics, Applied Financial Economics, Social Responsibility Journal and the American Journal of Finance and Accounting. E-mail: pkd8947@louisiana.edu

\section{REFERENCES}

1. Beranek, W. (1977). The weighted average cost of capital and shareholder wealth maximization. Journal of Financial and Quantitative Analysis, 12(1), 17-31. 
2. Bierman, H., \& Smidt, S. (1988). The capital budgeting decision. New York: Macmillan.

3. Brigham, E., \& Gapenski, L. (2008). Financial management theory and practice. Mason: ThompsonSouthwestern.

4. Ibbotson Associates (2006). Stocks, bonds, bills, and inflation 2006 yearbook: Valuation edition.

5. Woods, J., \& Randall, M. (1989). The net present value of future investment opportunities: Its impact on shareholders' wealth and implications for capital budgeting theory. Financial Management, 18(2), 85-92. 
NOTES 